\title{
CORRELATION OF EMPLOYMENT STATUS, MOTIVATION AND ACHIEVEMENT IN LEARNING
}

FIKRIANI AMINUN OMOLU

Teacher Training and Education of Universitas Muhammadiyah Palu

E-mail: fikasunset@gmail.com

\begin{abstract}
Fulltime students have more free time than working students. They can spare a lot of time on doing tasks from their lecturers and spend the rest to play or to do any other activity they like. While working students must share their time wisely to make a balance of studying and working. The hardship of balancing these two states in some ways, affects students' achievement in class. To get better achievement, there are many influencing factors. One of them is motivation. Coming across this situation, it becomes an interesting matter to find out correlation of students' employment status and achievement, students' motivation and achievement, and correlation of students' employment status and motivation simultaneously on achievement.
\end{abstract}

Keywords: Correlation, Employment Status, Motivation, Achievement. 


\section{A. INTRODUCTION}

Achievement means completing goal that one has set. For teachers, the goals could be the students reach the minimum standard score in school. For lecturers, achievement means $\mathrm{A}, \mathrm{B}, \mathrm{C}$, or D when $\mathrm{E}$ means they do not pass. Achievement of course is not only about what is written on the paper, but what is comprehended by the students, but then it brings us back that what has been comprehended can be recorded by numbers or letters. The condition also happens at Universitas Muhammadiyah Palu where letters $\mathrm{A}, \mathrm{B}, \mathrm{C}, \mathrm{D}$, and $\mathrm{E}$ indicates the comprehension of students.

Universitas Muhammadiyah Palu is a private university which its students are varied in terms of background, age, employment status, etc. In each department, there are students who have been working either full time or part time. This employed status of students has been giving them problems. For example in the semester IV of Teacher Training and Education Faculty of Universitas Muhammadiyah Palu, there were $44.73 \%$ employed students, while the rest were fulltime students. It means almost half of students in this class were struggling to balance their working hours and academic activities.

From preliminary observation, it is found that a working student had problem in managing their time between working and studying. Some of them even quit their study because the hard situation of matching the work time and class time. For example student A, who was employed, got GPA (Grade Point Average) 2.00. Unfortunately student $\mathrm{C}$, who quits studying because of working, got GPA 1.58. Related to this condition, it is interested to figure out if there is any correlation of students' employment status with their academic achievement.

Another important factor affecting achievement is motivation. Starting from a good motivation, students will do task, learning activity, and things related to their study better than those who do not have good motivation. This situation happened on the semester IV students of Teacher Training and Education Faculty of Universitas Muhammadiyah Palu. It was assumed that a student who was well motivated would have better performance and achievement compared to one who was not motivated. This condition raised a curiosity to find out the correlation of motivation and students' achievement at Universitas Muhammadiyah Palu.

After observing both of the variables, employment status and motivation from the students of Teacher Training and Education Faculty of Universitas Muhammadiyah Palu, the researcher came to an idea to relate both of the variables and find out the correlation on students achievement. With respect to the description from background of the study which showed the connection of Students' employment status, motivation and achievement, the questions of the research was 
highlighted as follows: Is there any significant and positive correlation between students' employment status and students' motivation on students' achievement partially and simultaneously at English Education Study Program of Teacher Training and Education Faculty of Universitas Muhammadiyah Palu? In relation with this, the objective of the research was to find out correlation between students' employment status and students' motivation on students' achievement partially and simultaneously at English Education Study Program of Teacher Training and Education Faculty of Universitas Muhammadiyah Palu.

\section{Motivation}

Motivation is a psychological condition where an individual get encouraged by someone or something in a particular way. It is what causes us to act, whether it is finding job to solve financial problem or reading a book to gain knowledge. Sinclair (2008) defines motivation as what moves someone to do something. Also in education, a thing that moves students to learn is called motivation. Then the thing that becomes question is what moves students to learn?

Due to the different reasons or goals that give rise to an action, there are different types of motivation. In the earlier studies, there are terms like instrumental orientation and integrative orientation (McDonough: 1983). Instrumental orientation in language learning refers to a desire to acquire a language for attaining instrumental goal. While integrative orientation indicates a learner of a language to integrate himself into the culture of the language he is learning. Harmer (1992) uses the term motivation instead of orientation. Recently, to see from the definition given, these orientations are commonly known as intrinsic and extrinsic motivation. Integrative motivation equals to intrinsic motivation while instrumental motivation equals to extrinsic motivation.

Extrinsic motivation is an urge comes from outside one's self that makes him doing something. Cherry (2014) states, "Extrinsic motivation occurs when we are motivated to perform a behavior or engage in an activity in order to earn a reward or avoid a punishment." Rewards in this kind of motivation can be money, prizes, grades or certain types of positive feedback. When an individual takes an advanced education level with a hope to get a higher position in their job, it means that he has extrinsic motivation in his self.

Intrinsic motivation is a thing comes from inside one's self that moves 
him to do something. Covington and Mueller (2001) define it as the will to do an interesting task without expecting or receiving a concrete reward for one's action. It means this motivation grows in one's heart without any influence from other factor. Cherry (2014) defines intrinsic motivation as a stimulus involves engaging in a behavior because it is personally rewarding; essentially, performing an activity for its own sake rather than the desire for some external reward. For example, a student who pursues further education and he does it because he wants to gain knowledge for himself and no other reason. This desire to gain knowledge comes from the student himself which means it is an intrinsic motivation.

\section{Employment Status}

Status is a state, a condition, or a situation. Employment status is a state where an individual is employed (employee and self-employed) or unemployed. In universities, regarding this employment status, there are two types of students; they are unemployed students and employed students. Perozzi, Rainey, and Wahlquist (2012) define student employment or employed students as any type of noncredit-bearing activity in which students participate and for which they receive financial compensation. For the compensation, students get risks to spare their time for the work and the rest for their study. Unemployed students for other party have the similar understanding with fulltime students. "Fulltime," in this context, usually means a schedule of 12 or more semester or quarter hours (Anonymous, 2013).

To have 12 or more schedule in a semester, a student is hardly to do other activity besides concentrating on their study. It means a student has to be unemployed to be able becoming full time student. Even so, there is no guarantee by becoming fulltime students or unemployed, they can finish the study on time. From Anonymous (2013: 2), a study done on 329 institutions in 30 states, covering 158 public two-year colleges, and 171 public four-year institutions, it is found:

- Most college students (69\%) were not enrolled in a schedule that would lead to on-time graduation, even if they never changed majors, failed a course, or took a class they didn't need.

- Even among "fulltime" students, most (52\%) were actually taking fewer than 15 hours, the standard course load that could lead to on-time graduation.

- At most two-year colleges, less than a third of "fulltime" students were taking 15 or more hours. 
- At four-year colleges, typically only $50 \%$ or fewer "fulltime" students were enrolled in 15 hours.

Having this result, somehow employment status of a student cannot be the only factor blamed for him/her gets low achievement in study. As the result of the study implemented by Watanabe (2005), the students' employment did not give any effect on their academic achievement. Employed students might still get high GPA and fulltime students can have low GPA score although they have more time compared to employed students.

Some students seem to be trapped with the idea of working to pay their study payment; consequently they choose to be employed students. When they are demanded to work properly, which means to give more attention on their job task, they lose concentration on their study, and it also happens on the contrary. Cameron (2008) affirms that working students often get far less out of their degree studies than they could. When employed students pay more attention on their study tasks, they sometimes forget with their responsibility at the work place. Regarding this circumstances, Perna (2012) states that it might create high levels of stress and anxiety, making it less likely that students will complete their degrees. At the end, it becomes a dilemma for them when they are faced with choices, to continue working and stop studying that means they get the money but are not able to get the knowledge and title, or to stop working and continue studying but they cannot afford the payment.

\section{Achievement}

Every teacher or lecturer has their own goal and standard in doing teaching and learning process. According to Farrel (2005: 4), “Whatever one's view concerning standards for head teachers, teachers, specialist teachers and others, the standards of attainment and achievement of pupils and the progress that they make cannot be ignored or marginalized." This statement indicates that achievement is an important matter in education. The success of not a teaching and learning process can be seen from the students' achievement which is the concrete one to be seen from their comprehension of a subject. It then help the teachers or lecturers to decide whether they need to improve the students' or achievement more or not, or to decide whether they need to use different methods, techniques or strategies from what they have used when most of the 
students' achievements are considerably failed.

Improving students' achievement is not a simple matter. Farrell (2005: 5) then implies that in raising the students' achievement there will be somehow hindrances in the teaching learning process. Raising the standards of pupils' attainment and achievement is not a hindrance that somehow gets in the way of learning. He also explains that better attainment and achievement are the essential indications that learning is taking place. Therefore, it is important to push for better attainment in all students.

\section{B. METHOD OF THE RESEARCH}

This research was to find out correlation of two independent variables and a dependent variable; students' employment status and motivation were the independent variables and students' achievement was the dependent variable. A correlational research design was used to conduct this research. According to Ary et al. (2010), correlational research is a nonexperimental research that is similar to ex post facto research in that they both employ data derived from preexisting variables. The research is described in the following diagram:
Correlation of Employment Status, Motivation and Achievement

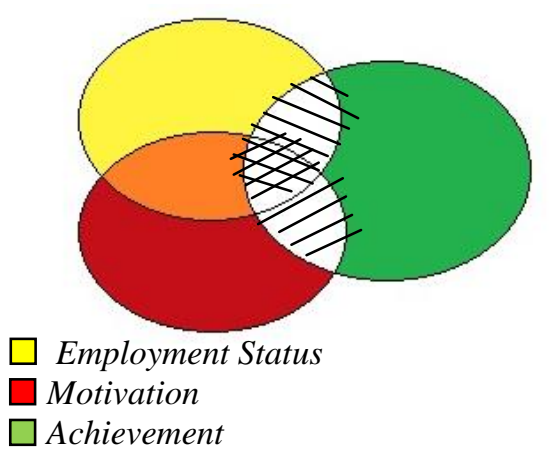

\begin{tabular}{|l|l|l|}
\hline$\underline{\text { Independent Variables }}$ & & Dependent Variable \\
\hline Employment status & $\longrightarrow$ & Students' achievement \\
\hline Motivation & $\longrightarrow$ & Students' achievement \\
\hline $\begin{array}{l}\text { Employment status \& } \\
\text { Motivation }\end{array}$ & $\longrightarrow$ & Students' achievement \\
\hline
\end{tabular}

Adapted from Ary et al. (2010)

In doing this research, population and sample of the research are needed to determine. Population is a group of individuals who have the same characteristics (Cresswell, 2005: 145). Sample is defined as a small part of the population that becomes the target of a research. Cresswell (2005: 145) states that a target of population is a group of individuals with some common defining characteristics that the researcher can identify and study. The population of this research was the students of English Education Study Program at FKIP Universitas Muhammadiyah Palu. The number of the population is 181 students. The sample of this research was selected using purposive sampling. The sample was the students of English Education Study Program at FKIP Universitas Muhammadiyah Palu from 
semester II, IV, and VI. The number of the sample was 84 students.

Instrument is one of the important parts in doing research. Ary et al. (2010: 414) express that researchers should involve careful planning, unbiased sampling of a population, thoughtful development of data-gathering instruments, and careful analysis of the results. Therefore, I provided the proper instruments to gather the data I needed. As one of the basic types of instruments, questionnaires were used in my research, while the other instrument was documentation. Documentation was needed in this research first was to mark whether the student was employed or unemployed and second to record the students' achievement. Questionnaires were used to collect data about students' motivation towards learning. The questionnaires used consisted of 20 items. It was measured by using Likert Scale. The scale used was:

Table of Scale Value

\begin{tabular}{|l|c|}
\hline \multicolumn{1}{|c|}{ Classification } & Scale Value \\
\hline $\begin{array}{l}\text { SA }=\text { Strongly } \\
\text { Agree }\end{array}$ & 5 \\
\hline $\mathrm{A}=$ Agree & 4 \\
\hline $\mathrm{U}=$ Undecided & 3 \\
\hline $\mathrm{D}=$ Disagree & 2 \\
\hline $\begin{array}{l}\mathrm{SD}=\text { Strongly } \\
\text { Disagree }\end{array}$ \\
\hline \multicolumn{2}{|c|}{ Adapted from Best (1981: 182) }
\end{tabular}

The questionnaires were formulated in Bahasa Indonesia in order to make the students understand the statements easily. It contains six indicators, they self efficacy, active learning strategy, English education learning value, performance goal, achievement goal, and learning environment stimulation. In order to have the validity and the reliability of the questionnaires items, I tried out the questionnaires for the students who do not belong to the sample of this research.

The technique used in this research was statistical technique because the analyzed data were in the form of numbers. To find the correlation between $\mathrm{X}_{1}$ and $\mathrm{X}_{2}$ toward $\mathrm{Y}$ (employment status and motivation toward students' achievement), I used multiple regressions analysis. Ary et al. (2010: 360) explain that multiple regression is a correlational procedure that examines the relationships among several variables. Here is the formula of multiple regressions proposed by Riduwan (2008):

\begin{tabular}{ll}
\hline & $\hat{\mathbf{Y}}=\mathbf{a}+\mathbf{b}_{\mathbf{1}} \mathbf{X}_{\mathbf{1}}+\mathbf{b}_{\mathbf{2}} \mathbf{X}_{\mathbf{2}}$ \\
Where: & $\hat{\mathrm{Y}}=$ Students' achievement \\
$\mathrm{a}=$ Constant number of $\mathrm{Y}$ if $\mathrm{X}$ \\
& \\
& $\mathrm{b}_{1}=$ regression coefficient $\mathrm{X}_{1}$ \\
status & $\mathrm{X}_{1}=$ Students' employment \\
& $\mathrm{b}_{2}=$ regression coefficient $\mathrm{X}_{2}$ \\
& $\mathrm{X}_{2}=$ Students' motivation
\end{tabular}

This formula indicated the regression of the three variables of the research.

To do multiple regression equation, all the variables were measured on an interval scale. Students' employment status was put in categorical scale 1 and 2. Brown and Rodgers (2003) define the categorical scales as scales 
that organize the data into categories or groups. In this research, 1 was signed to employed student and 2 was signed to unemployed students (full-time students). The data were qualitative and I computed the frequency. The other independent variable, as what has been stated previously, students' motivation was measured using Likert Scale.

Students' achievement and students' motivation were categorized in four and three quality categories. For students' achievement, the categories are Low, Fair, Good and Very Good. And for students' motivation, the categories are Strongly motivated, Motivated, and Less Motivated. The interval of score is arranged using a formula proposed by Nazir (2003):

$$
\text { Interval Range (i) }=\frac{R}{\mathrm{k}} \text {, }
$$

With the value of $R=\mathrm{H}-\mathrm{L}$

Where: $\mathrm{R}=$ Range

$\mathrm{H}=$ The highest score obtained $\mathrm{L}=$ The lowest score obtained

interval $\mathrm{k}=$ The number of Category

To know the level of correlation, the following table was used to interpret the level of correlation by using the value of $r$.

Table of Interval Correlation

\begin{tabular}{|c|c|}
\hline $\begin{array}{c}\text { Value of the } \\
\text { Correlation } \\
\text { Co-Efficient }\end{array}$ & $\begin{array}{c}\text { Strength of the } \\
\text { Correlation }\end{array}$ \\
\hline 1 & Perfect \\
\hline $0.8-0.9$ & Very Strong \\
\hline $0.5-0.8$ & Strong \\
\hline $0.3-0.5$ & Moderate \\
\hline $0.1-0.3$ & Modest \\
\hline$>0.1$ & Weak \\
\hline 0 & Zero \\
\hline
\end{tabular}

Adopted from Dancey and Reidy (2004)
Whether employment status and motivation could affect students' achievement or not, the researcher used SPSS (Statistical Package for Social Science) by applying regression. The partial correlation would be measured by $\mathrm{t}$-test that would compare the $\mathrm{t}$ counted in Coefficients Table and score in $\mathrm{t}$ table, while simultaneous correlation would be measured by doing F-test, which would compare the F-countedin ANOVA (Analysis of Variance) table and score in F-table.

\section{FINDINGS AND DISCUSSION}

The data collection was done in approximately 1 month, started in September 2014 to October 2014. The research began with questionnaires tryout to measure its validity and reliability. The result of tryout was then analyzed using SPSS 18. The tryout was conducted in FKIP Universitas Tadulako on 30 students of Semester V of English Education Study Program. Numbers of questionnaires items tested were 20 items. From all the items tested, the Pearson correlation score for item number 1 was -0.007 which is lower than r-table score, 0.3494 that is found from $n=30$ and significance 0.05 . It means this item was categorized as not valid. The item was then deleted. Whether the questionnaires itemswere reliable or not, I compared Cronbach's Alpha value 
obtained with Cronbach's Alpha of each questionnaires item. If it is found that Cronbach's Alpha of an item is greater than the Cronbach Alpha of reliability, then the item is invalid. The Cronbach's Alpha value of reliability statistics obtained from the tryout of the questionnaires was 0.792 of 20 items of questionnaire tested. Compared with Cronbach's Alpha if Item Deleted, I found that one of the Cronbach' Alpha item is greater. It isitem number 1 with Cronbach' alpha value 0.800 . Therefore, considering the item is not reliable, it is then deleted.

Completing the validity and reliability test of the questionnaires, then the data gathering was started. After determining the interval and quality category for students' motivation using the formula provided previously, students' motivation then categorized into three motivation quality, strongly motivated, motivated, and less motivated. From 83 students of semester II, IV, and VI, there were 16 students or $19.3 \%$ in strongly motivated category, 45 students or $54.2 \%$ in motivated category, and 22 students or $26.5 \%$ were in less motivated category.

From documentation of students' employment status, it is found that there were 28 students or $33.7 \%$ employed students and 55 students or $66.3 \%$ were fulltime students in FKIP Universitas Muhammadiyah Palu Academic Year 2013/2014.

Diagram Students' Employment Status and Motivation



Comparing the result of students' employment status and student's motivation, I found that $13.8 \%$ of employed students are categorized as strongly motivated. The other $55.2 \%$ of the employed students are categorized as motivated. The rest $31 \%$ of the employed students are in the less motivated category. While for fulltime students, there are $22.2 \%$ students categorized as strongly motivated, $53.7 \%$ categorized as motivated, and $24.1 \%$ students categorized as less motivated. From this data, it is noticed that fulltime students are more motivated that employed students considering that there are $75.9 \%$ fulltime students in total for strongly motivated and 
motivated category. This percentage is higher than the percentage of strongly motivated and motivated students with employed status, $69 \%$.

After documenting the data of students' achievement, interval and quality category was determined. The categories are as follows:

Table of GPA Quality Category Interval

\begin{tabular}{|c|c|c|}
\hline GPA & Category & Qualification \\
\hline \hline $3.23-3.91$ & Very Good & Successful \\
$2.54-3.22$ & Good & Successful \\
$1.85-2.53$ & Fair & Successful \\
$1.16-1.84$ & Low & Failed \\
\hline
\end{tabular}

Having these four categories, from the data of students' achievement it was found that out of 83 students, 32 students of $38.6 \%$ were categorized into Very Good, 45 students or $54.2 \%$ were in Good category, three students or $3.6 \%$ were in Fair category, and three students or $3.6 \%$ were in low category.

To see how the employed students' achievement is compared to fulltime students, the next diagram is provided.

Diagram Students' Employment Status and Achievement

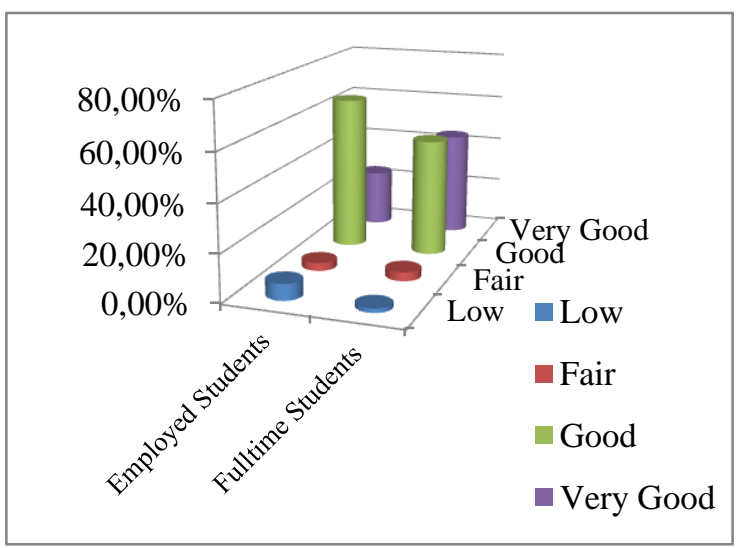

A slight difference is seen in fair category, fulltime students got higher percentage than employed students, and it is $3.8 \%$ versus $3.4 \%$. In very good category, fulltime students got much higher percentage with $44.4 \%$ compared to employed students with half of it, $24.1 \%$. But a surprising result that fulltime students got lower percentage in good achievement category with $50 \%$ compared to employed students with $65.5 \%$.

The next diagram 4.6 will exemplify students' motivation and their achievement. By comparing these two variables, it will be seen in what category of achievement reached by less motivated, motivated, and strongly motivated students.

Diagram Students' Motivation and Achievement

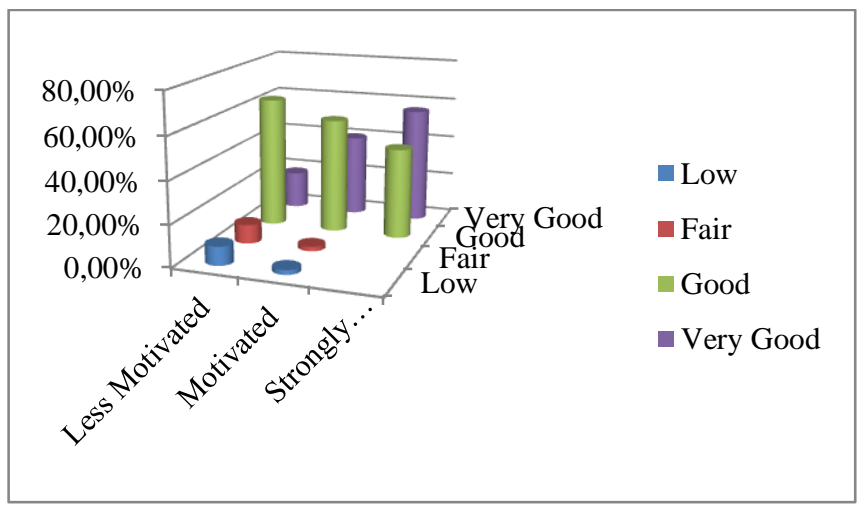

The diagram indicates that students with less motivation have higher percentage of achievement in low and fair category compared to motivated and strongly 
motivated students. They only have higher percentage in good achievement category with $63.6 \%$. But the highest percentage was in very good category achieved by strongly motivated students, on the contrary. The lowest percentage in this category was achieved by students with less motivation with only $18.2 \%$.

\section{Students' Employment Status,}

\section{Motivation, and Achievement}

From the SPSS analysis, the data provided and then interpreted as follows. Table of Correlation (table 4.15) helps us to see the correlation of students' employment status and their achievement.

Table of Correlations

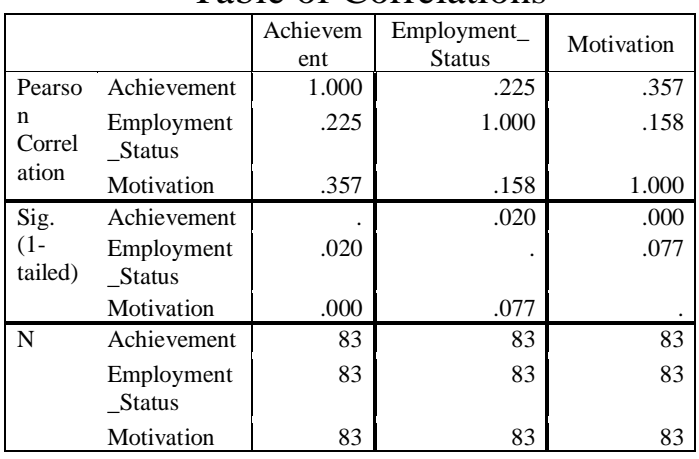

From the table, it is found that the score is 0.225 . The score displayed in the table for Employment Status indicates that the correlation is positive for there is not any () sign before the score. To observe the interval correlation table proposed in chapter 3 , this score is indicating a modest correlation between students' employment status and students' achievement.

A t-test is needed to see whether the correlation of students' employment status and achievement is significant or not. This also altogether tests the first hypothesis whether there is a significant and positive correlation between students' employment status and achievement.

Table of Coefficients

\begin{tabular}{|c|c|c|c|c|c|}
\hline \multirow{2}{*}{ Model } & \multicolumn{2}{|c|}{$\begin{array}{l}\text { Unstandardized } \\
\text { Coefficients }\end{array}$} & \multirow{2}{*}{$\begin{array}{c}\begin{array}{c}\text { Standardized } \\
\text { Coefficients }\end{array} \\
\text { Beta }\end{array}$} & \multirow{2}{*}{$\mathrm{T}$} & \multirow{2}{*}{ Significance } \\
\hline & B & $\begin{array}{l}\text { Std. } \\
\text { Error }\end{array}$ & & & \\
\hline ] (Constant) & .963 & .571 & & 1.686 & .096 \\
\hline $\begin{array}{l}\text { Employme } \\
\text { nt_Status }\end{array}$ & .180 & .108 & .173 & 1.664 & .100 \\
\hline Motivation & .024 & .007 & .330 & 3.169 & .002 \\
\hline
\end{tabular}

a. Dependent Variable: Achievement

From the table displayed above, the general form of the equation to predict Achievement from employment status and motivation is:

\section{Achievement $=0.963+(0.180 x$ Employment status $)+(0.024 x$ Motivation)}

T-score for employment status displayed in table is 1.664. Meanwhile, tvalue in the t-table for degree of freedom 80 and significance 0.05 is 1.664 . These scores are equals. To see the significance score of employment status, 0.100 , which is greater than the alpha, 0.05 , it means the correlation is not significant. Having this result, the first hypothesis is still 
considered accepted. There is positive correlation between students' employment status and achievement but the correlation is not significant. This result is somehow unexpected.

From all the tables and score obtained in the data provided, it indicates that there is positive correlation between students' employment status and their achievement. It means that status with higher number will have higher achievement. In other words, full-time students or unemployed students which is assigned to score 2 have a bigger chance to have higher achievement. But for the poor correlation, it is found this model of correlation is not significant. Similar result also achieved by Watanabe (2005) that employed students with many indicators in the status like work hours and type of job, does not always get low achievement. In other word, college student employment did not affect academic achievement significantly. Pinto, Parente, \& Palmer (2001), after comparing high and low academic performance and the amount of hours students worked, found that the amount of hours employed did not have an adverse effect on their academics. Likewise, Watts (2002) investigated 19 students at the University of Brighton, he found that 4 of 12 working undergraduates said that working did not affect their academics and 5 said that it actually had a positive impact.

The insignificant correlation of Employment status and achievement is caused by the factors of students' type of job and their studying schedule in university. Among the employed students, there are students who work as English teachers, hotel receptionists, Café waitress/waiter. For students of English Education Study Program, these types of job somehow help them practicing the knowledge they get from university. For example, when a student works as English teacher, he/she practice his/her knowledge, learns more to teach better, and discusses difficulty he/she gets in working with lecturers in the university. These would make the students pay more attention on their study and have the chance to study while working. It also applies on the students who work as hotel receptionists. It is not a rare chance for them to meet foreigner guests and like or dislike it makes them have to directly practice their speaking skill. This also helps them with their study. The schedule of their study in university also helps them to manage their time in their work. For Semester II of 
University Muhammadiyah Palu, the classes are scheduled in the afternoon. It makes the employed students able to match their morning working time with the afternoon classes. While for semester IV and VI, half of the classes are scheduled in morning and half of them are in the afternoon. This situation make students who work part-time able to manage taking suitable shift to match their study and work schedule.

The correlation level of students' motivation and achievement is indicated by the score 0.357 in the correlation table (Table 4.15). This gives indication that the independent variable, students' motivation correlates moderately with students' achievement. The fact that the correlation coefficients have positive values means that the increases in students' motivation to increase their achievement. In other words, the higher motivation students have, the better achievement they get.

Finding that the correlation is in moderate level, this is actually unexpected. For so many researchers done before, motivation almost always has strong correlation with students' achievement. This result is caused by process of questionnaire distribution and the way of the students filling in the questionnaires.
Some of the questionnaires were distributed in the class before or after the class. It makes the students did not have sufficient time to fill in the questionnaire properly.

Applying the T-test is to find out whether the correlation of students' motivation is significant or not toward the students achievement. From the coefficient table it is found that $\mathrm{t}$-counted for Motivation is 3.169. While the t-table score for degree of freedom 80 and significance 0.05 is 1.664 . The score of $t-$ counted is greater than t-table score. The significance score shown in the table is 0.002, which is much lower the alpha, 0.05. It means students' motivation correlates significantly to their achievement. Having this result, the second hypothesis that there is a significant and positive correlation between students' motivation and students' achievement is accepted.

This result points out that students' motivation always gives effects on their achievement. Motivated students will give more efforts to get good achievement, like manage time to study outside the class, do group discussion to solve difficult problems with their friends. Students with high motivation will also directly find the 
books that recommended by the lecturers in order to get the knowledge which will bring them to have good achievement. Motivation will also make students to participate actively in the class. It is also able to push students to do their assignments individually in order to test their self whether they have understood the material or not. By all these efforts done, good achievement will surely be achieved by the students.

This research is also proposed to find out the correlation of students' employment Status and motivation on achievement. First, to see whether both independent variables can be predictors to the dependent variable, the standard error of estimate and standard deviation are provided.

Table of Descriptive Statistics

\begin{tabular}{|l|r|r|r|}
\hline & Mean & \multicolumn{1}{|c|}{$\begin{array}{c}\text { Std. } \\
\text { Deviation }\end{array}$} & \multicolumn{1}{c|}{ N } \\
\hline Achievement & 3.0647 & .49984 & 83 \\
Employment_- & 1.6506 & .47968 & 83 \\
Status & & & \\
Motivation & 76.6747 & 7.00193 & 83 \\
\hline
\end{tabular}

Data output from Table 4.8 in the previous page indicates that mean score of achievement from 83 students is 3.0647 with standard deviation 0.49984. Then mean score of Motivation is 76.6747 with standard deviation 7.00193. Whilst mean score of Employment Status is 1.6506 with standard deviation 0.47968 .

Table of Model Summary

\begin{tabular}{|c|c|c|c|c|c|c|c|c|c|}
\hline \multirow[b]{2}{*}{$\begin{array}{c}\text { Mod } \\
\text { el }\end{array}$} & \multirow[b]{2}{*}{$\mathrm{R}$} & \multirow[b]{2}{*}{$\begin{array}{c}\mathrm{R} \\
\text { Squ } \\
\text { are }\end{array}$} & \multirow[b]{2}{*}{$\begin{array}{c}\text { Adjus } \\
\text { ted R } \\
\text { Squar } \\
\text { e }\end{array}$} & \multirow[b]{2}{*}{$\begin{array}{c}\text { Std. } \\
\text { Error } \\
\text { of the } \\
\text { Estimat } \\
\text { e }\end{array}$} & \multicolumn{5}{|c|}{ Change Statistics } \\
\hline & & & & & $\begin{array}{c}\mathrm{R} \\
\text { Squar } \\
\mathrm{e} \\
\text { Chang } \\
\mathrm{e}\end{array}$ & $\begin{array}{c}\text { F } \\
\text { Chang } \\
\text { e }\end{array}$ & df1 & df2 & $\begin{array}{c}\text { Sig. F } \\
\text { Chang } \\
\text { e }\end{array}$ \\
\hline 1 & $\begin{array}{r}.39 \\
6^{\mathrm{a}}\end{array}$ & .157 & .135 & .46475 & .157 & 7.425 & 2 & 80 & .001 \\
\hline
\end{tabular}

a. Predicators: (Constant), Motivation, Employment status

b. Dependent Variable: (Achievement The standard error of estimate indicated in the Model Summary table is 0.46475, while the standard deviation found in the Descriptive Statistics table for achievement is 0.49984, where the standard error is lower than standard deviation. It means that both variables can be predictors for students' achievement. To say these two variables, students' employment status and motivation can be predictor on students' achievement, it means that we can predict how would the achievement of a students by seeing his/her employment status and their motivation. As explained in the previous subchapters, both variables have positive correlation to achievement. Therefore, we can predict that employed students with low motivation might have low achievement, and as the opposite, full-time students with 
high motivation might have high achievement.

Second, to see how these two independent variable correlates to the dependent variable, the $\mathrm{R}$ score is needed. In the Model Summary table, the R score is 0.396 and the $\mathrm{R}$ squared was 0.157 . This score is indicating that the level of prediction of students' employment status and motivation on the achievement is 0.396 or all the independent variables affect the dependent variable $15.7 \%$ and the rest or $84.3 \%$ is affected by other variables except the independent variables investigated. This result confirms that, for example, a good achievement get by a student is $15.7 \%$ affected by his/her employment status and motivation. Meanwhile, $84.3 \%$ might be affected by other factors like the situation of the class, the lecturers, the facility, background, etc.

Third, to see whether students' employment status and students' motivation simultaneously correlates to their achievement, F-test is done.

Table of ANOVA

\begin{tabular}{|cc|c|r|r|r|r|}
\hline \multicolumn{1}{|c|}{ Model } & $\begin{array}{c}\text { Sum of } \\
\text { Squares }\end{array}$ & df & $\begin{array}{c}\text { Mean } \\
\text { Square }\end{array}$ & F & $\begin{array}{c}\text { Signifi- } \\
\text { cance }\end{array}$ \\
\hline 1 & $\begin{array}{l}\text { Regr } \\
\text { essio } \\
\mathrm{n}\end{array}$ & 3.207 & 2 & 1.604 & 7.425 & $.001^{\mathrm{a}}$ \\
& $\begin{array}{l}\text { Resi } \\
\text { dual } \\
\text { Total }\end{array}$ & 17.279 & 80 & .216 & & \\
& 20.487 & 82 & & & \\
\hline
\end{tabular}

The table of ANOVA displayed the Fcounted of this correlation model and the score is 7.425 . The F-table score for degree of freedom 80 and significance level 0.05 is 3.11. It is smaller than the score of Fcounted. The regression significance score is 0.001, which smaller than the alpha, 0.05. It means the correlation is significant. This result also means that the third hypothesis, there is a significant and positive correlation of students' employment status and motivation simultaneously on students' achievement, is accepted. The result indicates that the two variables, students' employment status and motivation simultaneously affect students' achievement. Full-time students with good motivation would have bigger possibility to get good achievement.

\section{CONCLUSIONS}

Students' employments status correlates positively to students' achievement but the correlation is not significant. This insignificance is caused by the type of job that the students do precisely helps them in their studying. The flexible class schedule also contributes in having such result. In the meantime, students' motivation correlates significantly and positively to their 
achievement in moderate level of correlation. For the correlation of students' employment status and motivation simultaneously on achievement, it is proved to have significant and positive correlation. From the SPSS analysis, it is found that students' employment status and motivation simultaneously affect the students' achievement. The level of prediction is 0,396 or it signifies that employment status and motivation influence students' achievement by $15.7 \%$. These results mean; fulltime students will have higher chance to have well achievement compared to employed students; students with strong motivation are proved having better achievement compared to less motivated students; strongly motivated full times students will have better achievement than employed students with strong motivation or on the contrary, less motivated employed students will have lower achievement than less motivated fulltime students.

\section{REFERENCES}

Anonymous. 2013. How Fulltime are "Fulltime" Students. Policy Brief Commissioned by Complete College America. http://completecollege.org/pdfs/2013-1014-how-fulltime.pdf.[08/18/14]
Ary, D., Jacobs, L.C., and Sorenson, C.K. 2010. Introduction to Research in Education. Belmont. Wadsworth, Cengage Learning.

Best, J. W. 1981. Research in Education. London. Prentice-Hall International.

Brown, J. D. and Rodgers, T. S. 2003. Doing Second Language Research. New York. Oxford University Press.

Cameron, S. 2010. The Bussiness Students' Handbook. Learning Skill for Study and Employment. Edinburgh. Ashford Colour Press Ltd.

Cherry, K. 2014. What Is the Difference Between Extrinsic and Intrinsic Motivation?http://psychology.about.com/ $\mathrm{od} / \mathrm{motivation} / \mathrm{f} / \mathrm{difference-between-}$ extrinsic-and-intrinsic-motivation.htm [07/05/14]

Covington, M. V. and Mueller, K. J. 2001. Intrinsic Versus Extrinsic Motivation: An Approach/Avoidance Reformulation. An Article: Educational Psychology Review, Vol.13, No.2, 2001.

Dancey, C. andReidy, J. 2004. Statistics without Maths for Psychology: using SPSS for Windows. London. Prentice Hall.

Farrell, M. 2005. Key Issues in Special Education: Raising Standards of Pupils' Attainment and Achievement. New York. Routledge.

Harmer, J. 1992. The Practice of English Language Teaching. New Edition. New York. Longman Publishing.

McDonough, S. H. 1983. Psychology in Foreign Language Teaching. London: Geoge Allen \& Unwin Publishers.

Nazir, M. 2003. Metode Penelitian. Jakarta. Ghalia Indonesia. 
Perna, L. W. 2012. Understanding the Working College

Student.http://www.aaup.org/article/under standing-working-college-student [08/18/14]

Perozzi, B., Rainey, A., and Wahlquist, Z. 2012. A review of the effects of student employment on academic achievement.

An article. http://www.acui.org/content.aspx?menu_i $\mathrm{d}=122 \& \mathrm{id}=2170[11 / 19 / 14]$

Pinto, M.B., Parente, D.H., and Palmer, T. S. 2001. College student performance and credit card usage. Journal of College Student Development, 42,1, 49-58.

Riduwan. 2008. Metode dan Teknik Menyusun Tesis. Bandung. Penerbit Alfabetani.

Sinclair, C. 2008. Motivation and Practice for The Classroom: How Can What We Know About Motivation to Teach Improve the Quality of Initial Teacher Education and its Practicum? Rotterdam: Sense Publishers.

Watanabe, L. E. 2005. The Effects of College Student Employment on Academic Achievement. The University of Central Florida Undergraduate Research Journal, Vol. 1: 38-47.

Watts, C. 2002. The effects of term-time employment on academic performance. Education + Training, 44,2, 67-75. 